\title{
LEARNING CYCLE 5E DALAM MENINGKATKAN KEMAMPUAN KOMUNIKASI MATEMATIS DAN SELF-REGULATED LEARNING MATEMATIKA
}

\author{
Jaya Dwi Putra \\ Departemen Matematika, Universitas Riau Kepulauan, Batam \\ Jayadwi_putra@yahoo.com
}

\begin{abstract}
ABSTRAK
Model Learning Cycle 5E (LC 5E) berlandaskan pada pendekatan konstruktivisme, yang memasukan keterampilan berpikir tingkat tinggi, merangsang siswa untuk melakukan eksplorasi, menemukan dan memperoleh pengalaman. Model LC 5E juga memfasilitasi proses pembelajaran dan memberikan kesempatan kepada siswa untuk belajar secara bermakna. Tujuan pembelajaran matematika di antaranya adalah meningkatkan kemampuan komunikasi matematis serta SelfRegulated Learning (SRL) matematika siswa. Kemampuan komunikasi matematis siswa diharapkan dapat meningkat melalui pembelajaran LC 5E yaitu, pada tahap explanation siswa dituntut untuk menjelaskan ide yang telah mereka peroleh berdasarkan hasil kegiatan exploration. Tahap elaboration siswa difasilitasi untuk mengaplikasikan ide dan gagasannya dalam menyelesaikan soal. SRL matematika siswa diharapkan dapat dikembangkan melalui pembelajaran LC 5E, yaitu pada tahap exploration siswa belajar bekerja sama dalam kelompok untuk mempelajari suatu topik serta pada tahap evaluation, siswa mengevaluasi hasil belajar dan mengevaluasi apa yang telah mereka pelajari dalam proses pembelajaran yang telah dilaksanakan.
\end{abstract}

Kata Kunci: Learning Cycle 5E, Konstruktivisme, Kemampuan Komunikasi Matematis, SelfRegulated Learning

\section{PENDAHULUAN}

LC 5E dikembangkan berdasarkan Learning cycle yang diusulkan oleh Atkin dan Karplus pada awal tahun 1960 dan digunakan dalam Science Curriculum Improvement Study (SCIS). Learning cycle Atkin dan Karplus terdiri atas tahapan exploration, invention dan discovery. Selanjutnya tiga tahapan tersebut dimodifikasi menjadi exploration, term introduction, dan concept application. Dalam BSCS ditambahkan sebuah tahapan awal untuk membangkitkan pengetahuan siswa yang telah dimiliki sebelumnya dan sebuah tahap akhir untuk mengevaluasi pemahaman siswa (Bybee at al., 2006).

Beberapa penelitian dalam bidang sains mengemukakan bahwa learning cycle efektif untuk meningkatkan penguasaan bahan pelajaran, mengembangkan penalaran ilmiah dan pengembangan ketertarikan dan sikap postitf terhadap sains (Madu \& Amaechi, 2012). Meskipun LC 5E dikembangkan BSCS untuk meningkatkan pendidikan sains, tetapi LC 5E telah diadaptasi dan digunakan untuk meningkatkan pembelajaran pada bidang lain, seperti pendidikan teknologi dan pendidikan matematika. Hasil penelitian Pulat (Bybee at al., 2006) 
mengenai 'Pengaruh LC 5E terhadap hasil belajar matematika dan sikap terhadap matematika pada siswa kelas 6', menunjukkan bahwa hasil belajar matematika siswa meningkat setelah belajar menggunakan LC 5E. Secara signifikan berpengaruh pada pengetahuan konsep dan prosedural dan meningkatkan sikap siswa terhadap matematika.

\section{Tahap-tahap Learning Cycle $5 E$ (LC 5E)}

Model pembelajaran LC 5E adalah model pembelajaran yang berpusat pada siswa. Model pembelajaran LC 5E merupakan salah satu model pembelajaran dengan pendekatan konstruktivisme yang terdiri atas 5 tahap: pembangkit minat (engagement), eksplorasi (exploration), penjelasan (explanation), elaborasi (elaboration), dan evaluasi (evaluation). Model pembelajaran LC 5E adalah model pembelajaran yang memberikan kesempatan kepada siswa untuk mengoptimalkan kemampuan matematis siswa dalam proses pembelajaran. Model pembelajaran LC 5E terdapat tahap-tahap kegiatan (tahap) yang diorganisasikan sedemikian rupa, sehingga siswa dapat mencapai kompetensi-kompetensi yang menjadi tujuan pembelajaran.

Proses pembelajaran menggunakan LC 5E guru berperan sebagai motivator dan fasilitator yang mengelola tahapan kegiatan pembelajaran, dimulai dari perencanaan pembelajaran (terutama perangkat pembelajaran), pelaksanaan pembelajaran (terutama pemberian pertanyaan-pertanyaan arahan dan proses bimbingan) dan evaluasi. LC 5E terdiri atas lima tahap yaitu (a) pembangkit minat (engagement), (b) eksplorasi (exploration), (c) penjelasan (explanation), (d) elaborasi (elaboration), dan (e) evaluasi (evaluation) (Lorsbach, 2002; $\quad$ Bybee et al, 2006; Madu \& Amaechi, 2012; Ergin, 2012). Kelima tahap tersebut dijabarkan sebagai berikut.

\section{Tahap Pembangkit Minat (Engagement)}

Guru mengajukan masalah untuk mendapat perhatian siswa. Tahap ini diikuti dengan asesmen pengetahuan awal siswa pada topik yang akan dipelajari. Guru menginformasikan kepada siswa mengenai tujuan pembelajaran yang akan dilakukan. Siswa mengingat kembali pengetahuan yang telah mereka ketahui, dan pengetahuan tersebut diperlukan mereka untuk diterapkan dalam pembelajaran. Guru mengajukan masalah kepada siswa untuk dieksplorasi pada tahap eksplorasi. Tahap ini merupakan titik awal pembelajaran dimulai. Untuk mengevaluasi tahap engagement, guru 
mengajukan pertanyaan yang spesifik pada topik yang ada untuk menentukan pengetahuan awal siswa. Siswa menjawab secara lisan.

\section{Tahap Eksplorasi (Exploration)}

Tahap eksplorasi merupakan tahap ke dua dari LC 5E. Pada tahap eksplorasi dibentuk kelompok-kelompok kecil yang terdiri 5-6 siswa dalam satu kelompok. Pada tahap ini siswa diberi kesempatan untuk bekerja sama dalam kelompok tanpa pembelajaran langsung dari guru. Pada tahap ini guru berperan sebagai motivator dan fasilitator.

Tujuan dari tahap eksplorasi adalah agar siswa mengumpulkan data yang dapat siswa gunakan untuk menyelesaikan masalah yang telah diajukan. Guru secara spesifik meminta siswa untuk (1) berpikir dengan bebas tetapi sesuai dengan tujuan pembelajaran; (2) mencari alternatif untuk permasalahan yang diajukan pada tahap engagement melalui diskusi dengan teman satu kelompok; (4) mencatat hasil observasi dan ide mereka;

(5) memberikan pendapat dalam diskusi kelompok. Untuk mengevaluasi tahap eksplorasi, guru menanyakan kepada siswa mengenai pertanyaan: (1) bagaimana data dikumpulkan oleh siswa? ; (2) apakah prosedur yang dilakukan benar? ; (3) bagaimana pencatatan data yang telah dikumpulkan? ; (4) apakah sudah tertib/rapi?

\section{Tahap Penjelasan (Explanation)}

Explanation merupakan tahap ke tiga dalam LC 5E. Pada tahap ini, guru memfasilitasi dan mendorong siswa untuk menjelaskan konsep dengan kalimat/pemikiran sendiri, meminta bukti dan klarifikasi atas penjelasan siswa dan saling mendengar secara kritis penjelasan antarsiswa atau guru. Dengan adanya diskusi tersebut, guru memberi definisi dan penjelasan tentang konsep yang dibahas dengan menggunakan penjelasan siswa terdahulu sebagai dasar diskusi. Untuk mengevaluasi tahap explanation, guru mengajukan pertanyaan kepada siswa mengenai proses pengumpulan data dan penggunaan data dalam penjelasan dan penarikan kesimpulan. Guru juga mengajukan pertanyaan pada bagian awal untuk menentukan pemahaman siswa.

\section{Tahap Elaborasi (Elaboration)}

Guru memberi siswa informasi baru yang merupakan perluasan dari apa yang telah mereka pelajari pada tahap sebelumnya. Pertanyaan yang diajukan pada tahap ini memungkinkan siswa untuk: (1) menerapkan definisi baru, menjelaskan dan menampilkan dalam bentuk baru tetapi dalam situasi yang sama; (2) menggunakan informasi sebelumnya untuk mengajukan pertanyaan, mengajukan solusi, membuat 
keputusan; (3) memaparkan alasan kesimpulan berdasarkan fakta; (4) mencatat observasi dan menjelaskannya; (5) memeriksa pemahaman satu sama lain. Evaluasi pada tahap elaboration, guru memberikan beberapa pertanyaan yang sebenarnya merupakan pertanyaan evaluasi.

\section{Tahap evaluasi (Evaluation)}

Evaluasi merupakan tahap terahkir dalam LC 5E. Pada tahap evaluasi, guru dapat mengamati pengetahuan atau pemahaman siswa dalam menerapkan konsep baru. Siswa dapat melakukan evaluasi diri dengan mengajukan pertanyaan terbuka dan mencari jawaban yang menggunakan observasi, bukti, dan penjelasan yang diperoleh sebelumnya. Hasil evaluasi ini dapat dijadikan guru sebagai bahan evaluasi tentang proses penerapan LC 5E sudah berjalan dengan sangat baik, cukup baik, atau masih kurang.

Tabel 1. Penerapan LC 5E dalam Proses Pembelajaran di Kelas

\begin{tabular}{|c|c|c|}
\hline No. Tahap LC 5E & Kegiatan Guru & Kegiatan Siswa \\
\hline \multirow[t]{3}{*}{ Tahap Engangement } & $\begin{array}{l}\text { Membangkitkan minat dan } \\
\text { keingintahuan siswa. }\end{array}$ & $\begin{array}{l}\text { Mengembangkan minat/rasa } \\
\text { ingin tahu terhadap topik } \\
\text { bahasan. }\end{array}$ \\
\hline & $\begin{array}{l}\text { Mengajukan pertanyaan } \\
\text { tentang proses faktual } \\
\text { dalam kehidupan sehari- } \\
\text { hari (yang berhubungan } \\
\text { dengan topik bahasan). }\end{array}$ & $\begin{array}{l}\text { Memberikan respon terhadap } \\
\text { pertanyaan guru. }\end{array}$ \\
\hline & $\begin{array}{l}\text { Mengaitkan topik yang } \\
\text { dibahas dengan } \\
\text { pengalaman siswa. } \\
\text { Mendorong siswa untuk } \\
\text { mengingat pengalaman } \\
\text { sehari-hari dan menunjukan } \\
\text { keterkaitannya dengan } \\
\text { pembelajaran yang sedang } \\
\text { dibahas. } \\
\text { Mengases pengetahuan } \\
\text { yang telah dimiliki dan } \\
\text { termasuk juga } \\
\text { miskonsepsi siswa }\end{array}$ & $\begin{array}{l}\text { Berusaha mengingat } \\
\text { pengalaman sehari-hari dan } \\
\text { menghubungkan dengan } \\
\text { topik pembelajaran yang } \\
\text { akan dibahas. }\end{array}$ \\
\hline \multirow[t]{2}{*}{ 2. Tahap Exploration } & $\begin{array}{l}\text { Meminta siswa } \\
\text { berkelompok, memberi } \\
\text { kesempatan untuk } \\
\text { bekerjasama dalam } \\
\text { kelompok kecil secara } \\
\text { mandiri. }\end{array}$ & $\begin{array}{l}\text { Membentuk kelompok dan } \\
\text { berusaha bekerja dalam } \\
\text { kelompok. }\end{array}$ \\
\hline & $\begin{array}{l}\text { Guru berperan sebagai } \\
\text { fasilitator. }\end{array}$ & Membuat prediksi baru. \\
\hline
\end{tabular}




\begin{tabular}{|c|c|c|}
\hline & $\begin{array}{l}\text { Mendorong siswa untuk } \\
\text { menjelaskan konsep } \\
\text { dengan kalimat mereka } \\
\text { sendiri. }\end{array}$ & $\begin{array}{l}\text { Mencoba alternatif } \\
\text { pemecahan dengan teman } \\
\text { sekelompok, mencatat } \\
\text { pengamatan, serta } \\
\text { mengembangkan ide-ide } \\
\text { baru. }\end{array}$ \\
\hline & $\begin{array}{l}\text { Observasi dan klarifikasi } \\
\text { penjelasan siswa, } \\
\text { mendengar secara kritis } \\
\text { penjelasan antar siswa. }\end{array}$ & $\begin{array}{l}\text { Menunjukan bukti dan } \\
\text { memberi klarifikasi terhadap } \\
\text { ide-ide baru. }\end{array}$ \\
\hline & $\begin{array}{l}\text { Memberi definisi dan } \\
\text { penjelasan siswa terlebih } \\
\text { dahulu sebagai dasar } \\
\text { diskusi. }\end{array}$ & $\begin{array}{l}\text { Mencermati dan berusaha } \\
\text { memahami penjelasan guru. }\end{array}$ \\
\hline \multirow[t]{4}{*}{ 3. Tahap Explanation } & $\begin{array}{l}\text { Mendorong siswa untuk } \\
\text { menjelaskan konsep } \\
\text { dengan kalimat mereka } \\
\text { sendiri. }\end{array}$ & $\begin{array}{l}\text { Mencoba memberi } \\
\text { penjelasan terhadap konsep } \\
\text { yang ditemukan. }\end{array}$ \\
\hline & $\begin{array}{l}\text { Meminta bukti dan } \\
\text { klarifikasi penjelasan } \\
\text { siswa. }\end{array}$ & $\begin{array}{l}\text { Menggunakan pengamatan } \\
\text { dan catatan dalam memberi } \\
\text { penjelasan. }\end{array}$ \\
\hline & $\begin{array}{l}\text { Mendengar secara kritis } \\
\text { penjelasan antarsiswa atau } \\
\text { guru. }\end{array}$ & $\begin{array}{l}\text { Melakukan pembuktian } \\
\text { terhadap konsep yang } \\
\text { diajukan. }\end{array}$ \\
\hline & Memandu diskusi. & berdiskusi. \\
\hline 4. Tahap Elaboration & $\begin{array}{l}\text { Mengingatkan siswa pada } \\
\text { penjelasan alternatif dan } \\
\text { mempertimbangkan } \\
\text { data/bukti saat mereka } \\
\text { mengeksplorasi situasi } \\
\text { baru. } \\
\text { Mendorong dan } \\
\text { memfasilitasi siswa } \\
\text { mengaplikasikan konsep } \\
\text { dalam seting yang baru. }\end{array}$ & $\begin{array}{l}\text { Menerapkan konsep dan } \\
\text { keterampilan dalam situasi } \\
\text { baru dan menggunakan } \\
\text { simbol dan definisi formal. } \\
\text { Bertanya, mengusulkan } \\
\text { pemecahan, membuat } \\
\text { keputusan, melakukan } \\
\text { percobaan, dan pengamatan. }\end{array}$ \\
\hline \multirow[t]{3}{*}{ 5. Tahap Evaluation } & $\begin{array}{l}\text { Mengamati pengetahuan } \\
\text { dan pemahaman siswa } \\
\text { dalam hal penerapan } \\
\text { konsep baru. }\end{array}$ & $\begin{array}{l}\text { Mengevaluasi belajarnya } \\
\text { sendiri dengan mengajukan } \\
\text { pertanyaan terbuka dan } \\
\text { mencari jawaban yang } \\
\text { menggunakan observasi, } \\
\text { bukti, dan penjelasan yang } \\
\text { diperoleh sebelumnya. }\end{array}$ \\
\hline & $\begin{array}{l}\text { Mendorong siswa } \\
\text { melakukan evaluasi diri. }\end{array}$ & $\begin{array}{l}\text { Mengambil kesimpulan } \\
\text { lanjut atas situasi belajar } \\
\text { yang dilakukannya. }\end{array}$ \\
\hline & $\begin{array}{l}\text { Mendorong siswa } \\
\text { memahami } \\
\text { kekurangan/kelebihannya } \\
\text { dalam kegiatan } \\
\text { pembelajaran. }\end{array}$ & $\begin{array}{l}\text { Melihat dan menganalisis } \\
\text { kekurangan/kelebihannya } \\
\text { dalam kegiatan } \\
\text { pembelajaran. }\end{array}$ \\
\hline
\end{tabular}

Sumber: Diadaptasi dari Bybee (1996) 


\section{Kelebihan dan Kekurangan Learning Cycle $5 E$}

Model pembelajaran Learning Cycle 5E berlandaskan pada pengalaman belajar dan pengetahuan awal yang dimiliki oleh siswa. Piaget (Dahar, 1989) dalam proses belajar anak akan membangun konsep-konsep melalui pengalamannya. LC 5E memfasilitasi siswa untuk secara aktif membangun konsep-konsep sendiri dengan cara berinteraksi dengan lingkungan fisik maupun lingkungan sosial.

Learning Cycle adalah model pembelajaran yang mengawinkan Advance Organizernya Ausubel dan Discovery Learningnya Bruner (Ajaja, 2004). Pada tahap engagement siswa menghubungkan pengetahuan yang telah mereka miliki dengan materi yang akan dipelajari, selanjutnya pada tahap exploration siswa melakukan eksplorasi untuk menemukan konsep sehingga proses pembelajaran bermakna. Proses pembelajaran yang bermakna dan dibangun atas dasar pengalaman sendiri sesuai pandangan konstruktivisme akan membuat pemahaman siswa lebih bertahan lama dan lebih dalam, pembelajaran yang bermakna dapat membantu siswa untuk selalu mengingat konsep-konsep yang telah siswa peroleh sehingga siswa dapat mengaitkan hubungan antar satu konsep dan konsep lainnya dalam matematika.

LC 5E memberikan kesempatan kepada siswa untuk mengungkapkan pengetahuan (khususnya kesalahpahaman siswa) dan memfasilitasi siswa berdiskusi dalam mengungkapkan ide-ide pengetahuan yang siswa miliki, proses ini dapat menyebabkan ketidakseimbangan kognitif dan dapat mengembangkan kemampuan berpikir tingkat tinggi siswa (Ajaja, 2004). Menurut Arif (Apriyani, 2010), kelebihan dan kekurangan penerapan pembelajaran menggunakan LC 5E yaitu:

\section{a. Kelebihan Penerapan LC 5E}

1) Meningkatan motivasi belajar karena siswa dilibatkan secara aktif dalam prosees pembelajaran

2) Membantu mengembangkan sikap ilmiah siswa

3) Pembelajaran menjadi lebih bermakna

\section{b. Kekurangan penerapan LC 5E}

1) Efektifitas pembelajaran rendah jika guru kurang menguasai materi dan langkahlangkah pembelajaran

2) Menuntut kesungguhan dan kreativitas guru dalam merancang dan melaksanakan proses pembelajaran

3) Memerlukan pengelolaan kelas yang lebih terencana dan terorganisasi 
4) Memerlukan waktu dan tenaga lebih banyak dalam menyusun rencana dan melaksanakan pembelajaran.

\section{Kemampuan Komunikasi Matematis}

Komunikasi merupakan bagian yang tak terpisahkan dalam kehidupan kita, begitu juga dalam proses pembelajaran matematika. $70 \%$ waktu manusia digunakan untuk berkomunikasi, komunikasi menentukan kualitas hidup manusia (Bistari, 2010). Komunikasi dalam pembelajaran di kelas melibatkan komunikasi antara guru dengan siswa, siswa dengan siswa, dan antara siswa dengan sumber belajar. Komunikasi merupakan kemampuan yang sangat penting dalam kegiatan pembelajaran, dan harus dikembangkan. Hal ini dikarenakan melalui komunikasi, gagasan-gagasan atau ide-ide menjadi objek refleksi, penghalusan, bahan diskusi dan perbaikan (NCTM, 2000). Yeager, A dan Yeager, R. (Izzati dan Suryadi, 2008) mendefinisikan komunikasi matematik sebagai kemampuan untuk mengkomunikasikan matematika baik secara lisan, visual, maupun dalam bentuk tertulis dengan menggunakan kosakata matematika yang tepat dan berbagai representasi yang sesuai, serta memperhatikan kaidah-kaidah matematika. Orang tidak akan memahami konsep dan solusi suatu masalah matematika atau mungkin salah menafsirkannya jika konsep dan solusi itu tidak dikomunikasikan dengan menggunakan bahasa matematis yang tepat.

Greenes dan Schulman (Saragih, 2007) mengemukakan bahwa komunikasi matematik merupakan: (1) Kekuatan sentral bagi siswa dalam merumuskan konsep dan strategi; (2) Modal keberhasilan bagi siswa terhadap pendekatan dan penyelesaian dalam eksplorasi dan investigasi matematika; (3) Wadah bagi siswa dalam berkomunikasi dengan temannya untuk memperoleh informasi, berbagi pikiran dan penemuan, curah pendapat, menilai dan mempertajam idea untuk meyakinkan yang lain. Berkaitan dengan peran kemampuan komunikasi, Sumarmo (2013) mengungkapkan bahwa salah satu kemampuan dasar matematika yang menjadi tujuan pembelajaran matematika adalah mengkomunikasikan gagasan dengan simbol, tabel, diagram, atau media lain untuk memperjelas keadaaan atau masalah, dalam hal ini adalah kemampuan komunikasi matematis.

Guru mempunyai peran penting dalam merancang pembelajaran sehingga siswa mempunyai kesempatan untuk berkomunikasi matematis. Agar kemampuan komunikasi matematis siswa terlatih, maka siswa perlu dibiasakan untuk berargumen atas setiap 
jawabannya dan memberikan tanggapan atas jawaban orang lain sehingga apa yang dipelajari menjadi lebih bermakna baginya (Pugalee, 2001). Selanjutnya, Brenner (1998) menemukan bahwa pembentukan kelompok-kelompok kecil memudahkan pengembangan kemampuan komunikasi matematis. Dengan adanya kelompok-kelompok kecil, maka intensitas seorang siswa dalam mengemukakan pendapatnya akan semakin tinggi. Berdasarkan pendapat tersebut kemampuan komunikasi matematis dapat dikembangkan melalui pembelajaran diskusi kelompok dan presentasi hasil diskusi kelompok. Hal ini akan memberi peluang yang besar bagi siswa untuk mengembangkan kemampuan komunikasi matematisnya.

Menurut Ernest (Kadir, 2010) komunikasi mencakup komunikasi tertulis dan komunikasi lisan. Komunikasi tertulis berupa penggunaan kata-kata, gambar, tabel dan sebagainya yang menggambarkan proses berpikir siswa. Komunikasi tertulis juga dapat berupa uraian pemecahan masalah atau pembuktian berbagai konsep untuk menyelesaikan masalah. Komunikasi tulisan menekankan pada interaksi siswa dalam dunia yang lebih kecil. Komunikasi lisan dapat berupa pengungkapan dan penjelasan verbal suatu gagasan matematika. Sejalan dengan yang dikemukakan Brenner (1998) bahwa komunikasi lisan dapat terjadi melalui interaksi antara siswa dengan guru ketika membangun tujuan pembelajaran dan antar siswa dalam pembelajaran dengan setting diskusi kelompok.

Baroody (1993) mengemukakan terdapat lima aspek komunikasi agar tidak terjadi miskonsepsi, kelima aspek tersebut adalah.

1. Representasi, diartikan sebagai; (1) bentuk baru dari hasil translasi suatu masalah atau ide dan (2) translasi suatu gambar dari model fisik ke dalam simbol atau kata-kata (NCTM, 1989). Misalnya bentuk peralihan ke dalam model konkrit, suatu diagram kedalam bentuk simbol. Representasi membantu siswa dalam memecahkan masalah, dalam mencari solusi dari suatu masalah yang disajikan secara abstrak, perlu adanya langkah awal dalam menyederhanakan masalah tersebut sehingga lebih mudah dipahami. Salah satu caranya yaitu dengan menyajikan masalah tersebut dalam berbagai bentuk representasi.

2. Mendengar (listening), dalam proses diskusi mendengar salah satu aspek penting. Kemampuan siswa dalam memberikan pendapat atau komentar sangat terkait dengan kemampuan dalam mendengarkan topik-topik utama atau konsep esensial yang didiskusikan. Siswa sebaikanya mendengar dengan hati-hati manakala ada pertanyaan dan komentar dari temannya. 
3. Membaca (reading), kemampuan membaca merupakan kemampuan yang kompleks, karena di dalamnya terkait aspek mengingat, memahami, membandingkan, menemukan, menganalisis, mengorganisasikan dan akhirnya menerapkan apa yang terkandung dalam bacaan.

4. Diskusi (discussing), merupakan sarana bagi seseorang untuk dapat mengungkapkan ide-ide matematis sehingga membantu siswa dalam mengasah pikirannya dan membuat hubungan-hubungan. Bila dalam diskusi ini terjadi perbedaan pendapat disaat mencari solusi ddari suatu permasalahan, diharapkan siswa dapat memahami matematika dengan lebih baik, karena dengan diskusi siswa akan belajar mengemukakan pendapat dan mengahargai pendapat orang lain. Kelebihan dari belajar diskusi antara lain; (1) dapat mempercepat pemahaman materi pembelajaran dan kemahiran menggunakan strategi; (membantu siswa mengkonstruksi pemahaman matematis (2) menginformasikan bahwa para ahli matematika biasanya tidak memecahkan masalah sendiri-sendiri tetapi membangun ide bersama pakar lainnya dalam satu tim (3) membantu siswa menganalisis dan memecahkan masalah.

5. Menulis (writing) merupakan kegiatan yang dilakukan secara sadar untuk mengungkapkan dan merefleksikan pikiran. Menulis dapat meningkatkan taraf berpikir siswa kearah yang lebih tinggi. Menulis dilihat sebagai cara siswa untuk merefleksikan atau menjelaskan dengan detail ide-ide matematis sehingga membantu siswa untuk mengungkapkan strateginya dalam meningkatkan pengetahuan proseduralnya dan mengahasilkan keuntungan kognitif secara umum (Kosko \& Wilkin, 2010).

Sumarmo (2013) menyatakan bahwa indikator kemampuan komunikasi matematis, meliputi (1) Menyatakan situasi, gambar, diagram, atau benda nyata ke dalam bahasa, simbol, ide, atau model matematik; (2) Menjelaskan ide, situasi, dan relasi matematika secara lisan dan tulisan; (3) Mendengarkan, berdiskusi, dan menulis tentang matematika; (4) Membaca dengan pemahaman suatu representasi matematika tertulis; (5) Membuat konjektur, menyusun argumen, merumuskan definisi, dan generalisasi; dan (6) Mengungkapkan kembali suatu uraian atau paragraf matematika dalam bahasa sendiri.

Untuk kepentingan penelitian ini, komunikasi matematis yang diukur melalui komunikasi siswa dalam mengungkapkan kemampuan komunikasi matematisnya secara tertulis dalam permasalahan matematis. Sehingga indikator kemampuan komunikasi matematis yang diukur adalah kemampuan menyatakan dan mengilustrasikan ide matematis ke dalam bentuk model matematis yaitu bentuk persamaan, notasi, gambar dan grafik, atau 
sebaliknya. Selanjutnya peneliti merinci indikator kemampuan komunikasi dalam penelitian ini adalah: (1) Menyatakan masalah dalam bentuk model matematis dari suatu permasalahan yang dinyatakan dalam bentuk gambar; (2) Menyatakan masalah matematis kedalam bentuk model matematis yaitu gambar dan grafik, menjelaskan ide, situasi dan relasi matematis; (3) Menyatakan peristiwa sehari-hari dalam bahasa atau simbol matematis, menjelaskan ide, situasi dan relasi matematis dalam bentuk model matematika.

\section{Self-Regulated Learning (SRL) Matematika Siswa}

Self-regulated learning (SRL) dalam Bahasa Indonesia berarti pengaturan diri dalam belajar. Zimmerman (2002) mendefinisikan SRL sebagai suatu proses mengaktifkan dan mempertahankan secara terus menerus pikiran, tindakan dan emosi kita untuk mencapai suatu tujuan tertentu. Jika tujuan yang akan dicapai berkaitan dengan belajar matematika, maka hal ini dinamakan sebagai mathematics self-regulated learning. Sedangkan Frank \& Robert (Sumarmo, 2013) mengemukakan bahwa SRL merupakan kemampuan diri untuk memonitor pemahamannya, untuk memutuskan saat ia siap diuji, untuk memilih strategi pemrosesan informasi yang baik.

SRL adalah proses kognitif mulai dari menghadirkan informasi atau instruksi, memproses dan mengintegrasikan pengetahuan dan mengulang informasi (Schunk, 2002). Selanjutnya, Bandura (Santrock, 2007) SRL adalah suatu strategi yang digunakan oleh individu dalam mencapai tujuan tertentu. Dengan demikian, SRL didefinisikan sebagai cara bagaimana seseorang merencanakan, memonitor, mengontrol, dan mengarahkan aspekaspek proses kognitif dan perilakunya demi mencapai prestasi terbaiknya dalam kegiatan belajar. Darr \& Fisher (2004) menyatakan bahwa siswa yang memiliki SRL adalah siswa yang secara aktif bisa memaksimalkan kesempatan dan kemampuannya untuk belajar. Mereka tidak hanya mampu mengontrol metakognisinya tetapi juga mengembangkan kemandirian sikap dan perilaku serta sumber daya yang dibutuhkan untuk meningkatkan hasil pembelajaran yang positif.

SRL matematika siswa sangat penting untuk dikembangkan dalam pembelajaran matematika baik di dalam kelas maupun di luar kelas. Hal tersebut, dikarenakan tuntutan kurikulum yaitu agar siswa mampu menghadapi dan menyelesaikan masalah di dalamkelas maupun diluar kelas dan mengurangi ketergantungan siswa terhadap orang lain dalam kehidupan sehari-hari. SRL siswa di dalam kelas akan mengefektifkan proses belajar yang berkaitan dengan pembelajaran yang bersifat student centered learning. 
Zimmerman (1989) mengemukakan tiga unsur dalam SRL, unsur-unsur tersebut addalah sebagai berikut. (1) Metacognitive, meliputi proses pemahaman akan kesadaran dan kewaspadaan diri serta pengetahuan dalam menentukan pendekatan pembelajaran sebagai salah satu cara di dalam proses berpikir. Kemampuan metakognisi mendukung proses SRL dengan merencanakan, menetapkan tujuan, memonitor, mengorganisasikan dan mengevaluasi bermacam-macam kegiatan belajar; (2) Motivational, individu yang memiliki motivasi adalah individu yang memiliki fokus terhadap pentingnya usaha luar biasa dan ketekunan dalam belajar. Menurut Borkowski et al. (Zimmerman, 1989) motivasi dalam SRL adalah situasi karakteristik yang menunjukkan efficacy yang tinggi, serta sifat diri dan ketertarikan terhadap tugas, adanya persepsi siswa mampu menyelesaikan tugas dan potensi siswa akan mencapai kesuksesan dan berani menghadapi kegagalan; (3) Behaviorally active participants, perilaku partisipasi aktif merupakan respon yang dipengaruhi oleh beberapa proses seperti perilaku yang baik yang ditampilkan pada suatu lingkungan. Perilaku partisipasi aktif adalah perilaku yang dapat diamati, dapat dilatih dan dikembangkan serta sifatnya adalah interaksi. Proses perilaku dalam SRL dikemukakan oleh Handerson et al. (Zimmerman, 1989) diantaranya memilih, menyusun, dan menciptakan lingkungan untuk belajar.

Siswa dalam mengikuti proses pembelajaran harus mengetahui tujuan belajarnya, sehingga mereka melakukan dan memilih sesuatu atas dorongan dari diri mereka sendiri dan bukan karena perintah orang lain. Woolfolk (Qohar, 2010) menyatakan bahwa faktor-faktor yang mempengaruhi SRL meliputi : pengetahuan (knowledge), motivasi (motivation) dan disiplin pribadi (self-discipline). Agar dapat mempunyai SRL siswa harus mempunyai pengetahuan tentang dirinya, tentang subyek yang akan dipelajari, tentang tugas, tentang strategi belajar dan tentang aplikasi dari subyek yang dipelajari. Siswa dengan SRL yang baik juga mempunyai motivasi belajar yang tinggi dan tertarik untuk mengerjakan berbagai tugas yang diberikan karena menyukainya. Siswa dengan SRL yang baik selain memiliki pengetahuan dan motivasi,mereka juga mempunyai disiplin pribadi yang baik. Hal ini sejalan dengan Corno (Qohar, 2010) menyatakan bahwa motivasi menunjukkan adanya komitmen, sedangkan disiplin pribadi menunjukkan adanya keberlanjutan. Kedisiplinan yang dimiliki siswa akan menjamin bahwa tindakan yang dilakukan akan berlangsung secara terus menerus sehingga diperoleh hasil yang lebih baik.

Sumarmo (2013) menyatakan bahwa SRL merupakan proses perancangan dan pemantauan diri yang seksama terhadap proses kognitif dan afektif dalam menyelesaikan 
suatu tugas akademik. Berdasarkan pendapat tersebut dapat dikatakan bahwa, apabila siswa mempunyai SRL yang tinggi, siswa tersebut cenderung belajar lebih baik. Hal ini didukung oleh studi temuan Hargis (Sumarmo, 2013) bahwa individu yang memiliki SRL cenderung belajar lebih baik, mampu memantau, mengevaluasi dan mengatur belajarnya secara efektif, menghemat waktu dalam menyelesaikan tugasnya, mengatur kegiatan dan waktu belajar secara efisien dan memperoleh skor yang tinggi dalam sains.

Indikator untuk mengukur kemampuan SRL matematika siswa dalam penelitian ini menggunakan indikator SRL adalah sebagai berikut: (1) Menunjukkan insiatif dalam belajar matematika; (2) Mendiagnosis kebutuhan dalam belajar matematika; (3) Menetapkan target/tujuan belajar; (4) Memonitor, mengatur dan mengontrol belajar; (5) Memandang kesulitan sebagai tantangan; (6) Memanfaatkan dan mencari sumber belajar yang relevan; (7) Memilih dan menerapkan strategi belajar; (8) Mengevaluasi proses dan hasil belajar; dan (9) Yakin tentang dirinya sendiri (self Efficacy) (Sumarmo, 2013).

\section{KESIMPULAN}

Tahap-tahap yang terdapat pada model pembelajaran LC 5E adalah sebagai berikut: (1) Tahap engagement, bertujuan mempersiapkan diri siswa dengan cara menggali minat dan rasa ingin tahu siswa tentang pokok bahasan matematika yang akan diajarkan. Menggali minat dan rasa ingin tahu siswa dengan mengaitkan materi pada kehidupan nyata di sekitar siswa; (2) Tahap exploration, siswa diberi kesempatan untuk bekerja sama dalam kelompokkelompok kecil agar terjadi tukar pikiran antar siswa; (3) Tahap explanation, guru mendorong siswa untuk menjelaskan ide yang telah mereka dapatkan, lalu ditampilkan dalam presentasi kelompok; (4) Tahap elaboration, siswa dapat mengaplikasikan ide serta gagasannya kedalam latihan soal, soal yang diberikan berupa soal kontekstual; (5) Tahap evaluation, dilakukan evaluasi pada siswa dengan mengoreksi hasil pekerjaan siswa dan menyimpulkan pelajaran yang telah diberikan. Kemampuan komunikasi matematis siswa diharapkan dapat meningkat melalui pembelajaran LC 5E yaitu, pada tahap exploration, explanation dan elaboration. Pada tahap exploration siswa bekerja sama dalam kelompok kecil, sehingga akan terjadi komunikasi antar siswa dalam proses pembelajaran dan menuliskan ide-ide mereka untuk menemukan suatu konsep. Pada tahap explanation, dapat mengembangkan kemampuan komunikasi karena pada tahap ini siswa dituntut untuk menjelaskan ide yang telah mereka peroleh berdasarkan hasil kegiatan exploration. Tahap elaboration, diharapkan dapat mengembangkan kemampuan komunikasi matematis, karena 
pada tahap ini siswa difasilitasi untuk mengaplikasikan ide dan gagasannya dalam menyelesaikan soal. SRL matematika siswa diharapkan dapat dikembangkan melalui pembelajaran LC 5E, yaitu pada tahap exploration dan evaluation. Pada tahap exploration siswa belajar bekerja sama dalam kelompok untuk mempelajari suatu topik, hal ini dapat mengembangkan SRL siswa kemudian pada tahap evaluation, siswa mengevaluasi hasil belajar dan mengevaluasi apa yang telah mereka pelajari dalam proses pembelajaran yang telah dilaksanakan sehingga diharapkan dapat meningkatkan SRL siswa.

\section{REFERENSI}

Ajaja, O. P., \& Eravwoke, U. O. (2004). Effects of 5E Learning Cycle on Students' Achievement in Biology and Chemistry.Cypriot journal of Educational Science. Vol. 7, 244-262. [Online]. Tersedia: http://www.world-educationcenter.org/index.php/cjes/article/view/7.3.9

Apriyani. (2010). Penerapan Model Learning Cycle "5E” dalam Upaya Meningkatkan Kemampuan Pemecahan Masalah Matematika Siswa SMP N 2 Sanden Kelas VIII pada Pokok Bahasan Prisma dan Limas. Skripsi UNY Yogyakarta: Tidak Diterbitkan. http://eprints.uny.ac.id/1405/1/SKRIPSI_APRIYANI.pdf

[Online].Tersedia:

Baroody, A.J. (1993). Problem Solving, Reasoning, And Communicating, K-8 Helping Children Think Mathematically. New York: Macmillan Publishing Company.

Bistari, BsY. (2010). Pengembangan Kemandirian Belajar Berbasis Nilai untuk Meningkatkan Komunikasi Matematik. Jurnal Pendidikan Matematika dan IPA. Vol. 1. No. 1. Januari 2010: 11-23.

Brenner, M. E. (1998). Development of Mathematical Communication in Problem Solving Groups by Language Minority Students. Bilingual Research Journal, 22:2, 3, \& 4 Spring, Summer, \& Fall 1998.

Bybee, R. W. (1997). BSCS 5E Instructional Model. [On-line]. Tersedia: http://www.mwsu.edu/ educ/coe/inquire/inquiry.htm

Bybee, R. W., et al. (2006). The BSCS 5E Instructional Model: Origins, Effectiveness, and Applications. [Online]. Tersedia: http://www.bscs.org/pdf/bscs5eexemummary.pdf.

Cai, J.L, \& Jakabcsin, M.s. (1996). The Role of Open-Ended Task and Holistic Scoring Rubrics: Assessing Students' Mathematical Reasoning and Communication. Dalam Portia C. Elliot dan Margaret J. Kenney (EDS), (h. 137-145). Communication in Matehematics K-12 and Beyond. Virginia: NCTM.

Dahar, R.W. (1989). Teori-Teori Belajar. Jakarta: Erlangga.

Darr, C. \& Fisher, J. (2004). Self-Regulated Learning in Mathematics Class. Paper presented at NZARE Conference, Turning the Kaleidoscope, Wellington, 24-26 November, 2004.

[Online].

Tersedia: http://www.nzcer.org.nz/system/files/13903.pdf

Ergin, I. (2012). Constructivist Approach Based 5E model and Usability Instructional Physiscs. Lat. Am. J. Phys. Educ. Vol. 6, No. 1, 14-20.

Izzati, N \& Suryadi, D. (2008). Komunikasi Matematik dan Pendidikan Matematika Realistik. Prosiding Seminar Nasional Matematika dan Pendidikan Matematika, Yogyakarta, UNY, 27 Nov 2010, ISBN : 978-979-16353-5-6. 
Johnson, E.B. (2010). Contextual Teaching \& Learning. Bandung: MLC.

Kadir. (2010). Penerapan Pembelajaran Kontekstual Berbasis Potensi Pesisir Sebagai Upaya Peningkatan Kemampuan Pemecahan Masalah Matematik, Komunikasi Matematik, dan Keterampilan Sosial Siswa SMP. Disertasi SPS UPI Bandung: tidak diterbitkan.

Kosko, K. W \& Wilkins, J. L. M. (2010). Mathemaical Communication and the Relation to the Frequency of Manipulative Use. International Electronic Journal of Mathematics Education. 5, (2), 79-90.

Lorsbach, A. W. (2002). The Learning Cycle as A tool for Planning Science Instruction. [Online]. Tersedia: (http://www.coe.ilstu.edu/scienceed/lorsbach/257lrcy.html). [12 Juni 2013].

Madu, B. C., \& Amaechi, C. C., (2012). Effect of Five-Step Learning Cycle Model on Students' Understanding of Concepts Related to Elasticity. Journal of Education and Practice. Volume 3, No. 9, 2012. [Online]. Tersedia:http://www.iiste.org/Journals/index.php/JEP/article/viewFile/2418/2434

National of Council Teacher of Mathematics. (2000). Curricullum and Evaluation Standards for School Mathematics. Reston, VA: NCTM

Pugalee, D.A. (2001). Using Communication to Develop Student's Mathematical Literacy. Journal Research of Mathematics Education 6(5) , 296-299. [Online]. Tersedia: http://www.nctm.org/ercsources/article-Summary.asp?Uri=MtMS2001-01296\& from $=\mathrm{B}$

Qohar, A. (2010). Mengembangkan Kemampuan Pemahaman, Koneksi dan Komunikasi Matematis serta kemandirian Belajar Matematika Siswa SMP melalui Reciprocal Teaching. Tesis SPS UPI Bandung: tidak diterbitkan.

Santrock, J.W. (2007). Educational Pyschology $2^{\text {nd }}$ Edition. Jakarta: Fajar Interpratama Offset.

Saragih, S. (2007). Mengembangkan Kemampuan Berpikir Logis dan Komunikasi Matematik Siswa Sekolah Menengah Pertama Melalui Pendekatan Matematika Realistik. Disertasi SPS UPI Bandung: tidak diterbitkan.

Schunk, D.H. (2002). Self-Regulated Through Goal Setting. (http://www.ericdigests.org).

Sumarmo, U. (2013). Kumpulan Makalah Berpikir dan Disposisi Matematik serta Pembelajarannya. Bandung: FMIPA UPI

Zimmerman, B.J. (1989). A Social Cognitive View of Self-Regulated Academic Learning. Journal of Educational Psychology. 81 (3). 1-23.

Zimmerman, B.J. (2002). Becoming a Self-Regulated Learner: An Overview. Journal of Educational Psychology. $41 \quad$ (2). 64-70. [Online]. Tersedia:.http://commonsenseatheism.com/wpcontent/uploads/2011/02/Zimmerma n-Becoming-a-self-regulated-learning 